\title{
Stabilizacija krhotina razrušenih stijena zagađenih otpadnom isplakom
}

\author{
S. Marinović, T. Troskot Čorbić, T. Goričnik, \\ N. Uzorinac Nasipak i V. Čizmek
}

Ina-Industrija nafte d. d., Lovinčićeva 4, 10000 Zagreb, Hrvatska

\begin{abstract}
Sažetak
Ključne riječi

Krhotine razrušenih stijena, stabilizacija, vapno, pijesak, opasni otpad
\end{abstract}

U hrvatskoj naftnoj industriji godišnje se proizvodi značajna količina krhotina razrušenih stijena. Krhotine razrušenih stijena zagađene su otpadnom isplakom te spadaju u heterogeni otpad koji sadrži ugljikovodike, teške metale i kloride. Trenutačno se kao metoda zbrinjavanja krhotina primjenjuje metoda stabilizacije uz pomoć vapna i pijeska. Opisan je postupak pripreme stabiliziranog otpada u laboratorijskim uvjetima na dva uzorka krhotina iz isplačnih jama s područja Dravske depresije. Prije pripreme stabiliziranog otpada u laboratorijskim uvjetima, u početnom uzorku otpada određen je udio organske tvari dobiven ekstrakcijom s organskim otapalom te sadržaj ukupno topljive tvari u vodi. Na temelju te dvije osnovne analize određena je količina vapna i pijeska potrebna za izradu stabiliziranog otpada. Fizikalno-kemijske značajke početnog i stabiliziranog otpada analizirane su primjenom standardnih laboratorijskih metoda. Rezultati su pokazali da miješanje otpada s vapnom i pijeskom omogućuje prevođenje početnog uzorka otpada klasificiranog kao opasan otpad u neopasan otpad.

\section{Uvod}

Tijekom postupka pripreme bušotinskog radnog prostora na lokaciji nove bušotine, uz bušaće postrojenje izrađuje se isplačna jama odgovarajućeg volumena (ovisno o konstrukciji bušotine) koja služi za odlaganje otpadne isplake i krhotina razrušenih stijena tijekom i nakon postupka bušenja. ${ }^{1} U$ slučaju nesreća tijekom izrade kanala bušotine $u$ isplačnu jamu se, osim krhotina i isplake, odlaže cementna kaša, isplaka za interventno gušenje, sirova nafta i slično. Nakon prestanka potrebe za upotrebom isplačne jame, tj. nakon završetka bušenja potrebno je pristupiti sanaciji isplačne jame. Postupak se odvija u dvije faze: (1) odvajanje tekuće faze i trajno odlaganje u podzemlje (utisna formacija) i (2) obrada preostale (ugušćene) faze miješanjem s pijeskom i vapnom radi prevođenja u neopasan otpad, njegovo trajno odlaganje u jamu i prekrivanje zemljom iskopanom tijekom izrade isplačne jame.

Krhotine razrušenih stijena su probušeni stijenski materijal koji nastaje u procesu bušenja i bivaju uklonjene iz kanala bušotine strujom bušaće isplake. Krhotine su obložene isplakom, koja obavlja funkciju podmazivanja i hlađenja bušaćih alatki, ispiranja bušaćih alatki i dna bušotine, sprječavanja korozije ugrađenih zaštitnih cijevi i bušaćih alatki te iznošenje krutih čestica (krhotina razrušenih stijena) na površinu i druge funkcije. ${ }^{2}$ Ovisno o značajkama bušenih stijena, načinu i specifičnim uvjetima bušenja, u praksi se upotrebljavaju različite vrste isplaka, od jednostavnih do vrlo kompleksnih, a mogu se podijeliti u tri osnovne skupine: isplake na bazi vode (najčešća upotreba), isplake na bazi ulja i sintetičke isplake. Isplake na bazi vode sadrže preko $70 \%$ vode, a u vodu se dodaju različiti aditivi ovisno o njihovoj funkciji, dok je osnovna komponenta isplaka na

*Autor za dopisivanje: dr. sc. Slavica Marinović

e-pošta: slavica.marinovic@ina.hr bazi ulja najčešće dizelsko gorivo i/ili mineralno ulje. ${ }^{3,4}$ Općenito, isplake na bazi ulja i sintetičke isplake su skuplje i imaju veći štetan utjecaj na okoliš od isplaka na bazi vode.

U Hrvatskoj se upotrebljavaju samo isplake na bazi vode, ${ }^{5}$ a uljne i sintetičke isplake se zbog ekoloških razloga i visoke cijene ne upotrebljavaju. Isplake na bazi vode su isplake u kojima je kontinuirana faza voda. Uglavnom se sastoje od četiri osnovne komponente: slatke ili slane vode, aktivnih koloidnih čestica, inertnih čestica i vodotopljivih aditiva. $U$ isplakama na bazi vode aktivne, čvrste koloidne čestice su gline (bentonit). Dodavanjem gline u vodu ili u isplaku dolazi do povećanja gustoće, viskoznosti i smanjenja filtracije. Inertne čestice u isplaci mogu se klasificirati kao oteživači isplake ili kao čestice razrušenih stijena. Gustoća bentonitne suspenzije često nije dovoljna za kontrolu slojnog tlaka, te se u nju moraju dodati oteživači da bi se postigla željena gustoća isplake. ${ }^{5}$ Kao oteživač isplake najčešće se upotrebljava barit $\left(\mathrm{BaSO}_{4}\right)$, zatim hematit, galenit i kalcijev karbonat. Aditivima se podešavaju svojstva isplake kako bi se djelotvorno odvijao proces bušenja. Aditivi koji se dodaju u isplaku mogu se prema svojoj funkciji podijeliti u grupe: viskoziferi, dispergatori, aditivi za smanjenje filtracije, podmazivači itd. ${ }^{5} \mathrm{~S}$ povećanjem dubine bušotine dolazi se u područja viših temperatura i tlakova, što zahtijeva dodatak odgovarajućih aditiva. Tipični dodatci isplaci, kao i njihova funkcija u isplaci prikazani su u tablici 1.

Zagađivala prisutna u krhotinama izravno ovise o kemijskom sastavu upotrijebljene isplake, kao i o litološkom sastavu formacije. Krhotine zagađene otpadnom isplakom uz stijenski materijal mogu sadržavati i veće količine ugljikovodika (npr. ukoliko se upotrebljavaju značajnije količine podmazivača u isplaci), vode, teških metala te u vodi topljive soli kao što su kloridi i sulfati. ${ }^{6,7}$ Zbog takvog sastava i potencijalnih štetnih utjecaja na okoliš, krhotine se ne smiju izravno zbrinjavati kao otpad bez prethodne obrade. 
Dva su osnovana problema vezana za otpad dobiven bušenjem naftnih i plinskih bušotina: otpad sadrži visok sadržaj ugljikovodika, ${ }^{8,9}$ (alifatski ugljikovodici, policiklički aromatski ugljikovodici (PAH), poliklorirani bifenili), a drugi razlog je visoka ukupna topljivost otpada, koja se najčešće manifestira u visokoj količini klorida i sulfata u eluatu, ${ }^{6,10}$ a ponekad i u visokom sadržaju teških metala u eluatu otpada, kao što su: barij, olovo, cink, živa, krom, arsen i nikal. ${ }^{11}$

Tablica 1 - Aditivi u isplaci na bazi vode i njihova funkcija u ispla$\mathrm{Ci}^{5}$

Table 1 - Additives in water based mud and their function in drilling mud $^{5}$

\begin{tabular}{|c|c|}
\hline $\begin{array}{l}\text { Naziv aditiva } \\
\text { Additives }\end{array}$ & $\begin{array}{l}\text { Funkcija u isplaci } \\
\text { Function in drilling mud }\end{array}$ \\
\hline $\begin{array}{l}\text { Barit } \\
\text { Barite }\end{array}$ & $\begin{array}{l}\text { Povećanje gustoće } \\
\text { Increasing density }\end{array}$ \\
\hline $\begin{array}{l}\text { Podmazivač } \\
\text { Base oil }\end{array}$ & $\begin{array}{l}\text { Smanjenje trenja } \\
\text { Reducing friction }\end{array}$ \\
\hline $\begin{array}{l}\text { Bentonit } \\
\text { Bentonite }\end{array}$ & $\begin{array}{l}\text { Povećanje viskoznosti, } \\
\text { smanjenje filtracije } \\
\text { Increasing viscosity, } \\
\text { decreasing filtration }\end{array}$ \\
\hline $\begin{array}{l}\text { Natrijev karbonat, } \mathrm{Na}_{2} \mathrm{CO}_{3} \\
\text { Sodium carbonate, } \mathrm{Na}_{2} \mathrm{CO}_{3}\end{array}$ & $\begin{array}{l}\text { Kontrola tvrdoće vode } \\
\text { Water hardness control }\end{array}$ \\
\hline $\begin{array}{l}\text { Natrijeva lužina, } \mathrm{NaOH} \\
\text { Caustic soda, } \mathrm{NaOH}\end{array}$ & $\begin{array}{l}\text { Kontrola } \mathrm{pH} \text { vrijednosti } \\
\text { Control of } \mathrm{pH} \text { value }\end{array}$ \\
\hline $\begin{array}{l}\text { Polimer } \\
\text { Polymer }\end{array}$ & $\begin{array}{l}\text { Dispergator } \\
\text { Dispersant }\end{array}$ \\
\hline $\begin{array}{l}\text { Polianionska celuloza (PAC) } \\
\text { Polyanionic cellulose (PAC) }\end{array}$ & $\begin{array}{l}\text { Povećanje viskoznosti, } \\
\text { smanjenje filtracije } \\
\text { Increasing viscosity, } \\
\text { decreasing filtration }\end{array}$ \\
\hline $\begin{array}{l}\text { Sol } \\
\text { Salt }\end{array}$ & $\begin{array}{l}\text { Salinitet } \\
\text { Salinity }\end{array}$ \\
\hline $\begin{array}{l}\text { Ksantan smola } \\
\text { Xanthan gum }\end{array}$ & $\begin{array}{l}\text { Podešavanje reoloških svojstava } \\
\text { Adjusting rheological properties }\end{array}$ \\
\hline $\begin{array}{l}\text { Škrob } \\
\text { Starch }\end{array}$ & $\begin{array}{l}\text { Smanjenje filtracije } \\
\text { Reducing filtration }\end{array}$ \\
\hline
\end{tabular}

\section{Stabilizacija krhotina razrušenih stijena zagađenih otpadnom isplakom}

Stabilizacija je kemijski proces kojim se smanjuje utjecaj štetnih tvari iz otpada, prevođenjem potencijalno opasnih tvari u slabo topljiv (inertan) otpad. Postupak se često primjenjuje u mnogim naftnim tvrtkama, a posebno je pogodan za sanaciju isplačnih jama, jer njegova primjena omogućava trajno odlaganje u isplačnoj jami, ${ }^{1}$ tj. otpad se ne mora transportirati na neko drugo mjesto (odlagalište). Kao aktivna komponenta za stabilizaciju najčešće se upotrebljavaju: portland cement, bentonit, vapno, termoplastične smole, zeoliti ${ }^{9}$ i dr. $U$ ovom radu prikazani su rezultati dobiveni primjenom živog vapna kao aktivne komponente za stabilizaciju krhotina razrušenih stijena zagađenih otpadnom isplakom.
Živo vapno (kalcijev oksid, CaO) je bijeli prah, kemijski vrlo inertan koji s vodom burno reagira prema jedn. (1) stvarajući slabo topljiv kalcijev hidroksid (gašeno vapno, $\left.\mathrm{Ca}(\mathrm{OH})_{2}\right)$.

$$
\mathrm{CaO}(\mathrm{s})+\mathrm{H}_{2} \mathrm{O}(\mathrm{l}) \leftrightarrow \mathrm{Ca}(\mathrm{OH})_{2}(\mathrm{~s})
$$

Reakcija je reverzibilna i zagrijavanjem kalcijev hidroksid ponovno prelazi u kalcijev oksid. Nastali kalcijev hidroksid uz dobro miješanje s krhotinama razrušenih stijena zagađenih otpadnom isplakom stvara krutinu koja je vrlo slabo topljiva u vodi ${ }^{1}$ (inertni otpad). Na taj način smanjuje se mogućnost ispiranja organskih i anorganskih zagađivala u okolišs.

Vapno je glavna komponenta koja utječe na stvaranje slabo topljivog otpada, međutim često je potrebno postići veću gustoću uzorka, tj. dobiti kompaktnu masu pogodnu za odlaganje $u$ isplačnu jamu. $U$ tu se svrhu uzorku početnog otpada dodaje i pijesak ili nezagađena zemlja. Postupak sanacije isplačne jame na terenu započinje uklanjanjem tekuće faze, nakon čega se provodi postupak stabilizacije ugušćene faze (krhotine razrušenih stijena s preostalom tekućom fazom). Miješanje, razastiranje, odlaganje i transport materijala obavljaju se upotrebom građevinskih strojeva - bagera (slika 1), buldožera i utovarivača.

Prije postupka sanacije na terenu u laboratoriju se miješaju otpadni materijal, vapno i pijesak kako bi se utvrdila količina vapna i pijeska koju treba dodati otpadu (izrada recepture) za postizanje optimalnog omjera koji omogućuje prevođenje početnog uzorka otpada klasificiranog kao opasni otpad u neopasni otpad.

Postupak sanacije isplačnih jama na području Dravske depresije provodi se u skladu s Glavnim rudarskim projektom (Glavni tipski rudarski projekt "Sanacija isplačnih jama u INA-Naftaplinu", INA-Naftaplin; Zagreb, 1990.) i Pojednostavljenom rudarskom projektu sanacije isplačne jame (Pojednostavljeni rudarski projekt sanacije jame za otpadne fluide bušotine Bk-42 na eksploatacijskom polju ugljikovodika "Bokšić-Klokočevci", Zagreb, 2018.). Pojednostavljeni rudarski projekt za istražnu bušotinu Severovci-1 još nije izrađen.

\section{Zakonska regulativa iz područja gospodarenja otpadom}

Europska unija je regulirala gospodarenje otpadom strogom zakonskom regulativom kako bi se osigurao visok stupanj zaštite stanovništva, prirode i okoliša. Direktive EU-a (Direktiva 2008/98/EZ o otpadu, Direktiva 1999/31/EZ o odlaganju otpada, kao i cijeli niz drugih direktiva EU-a iz područja posebnih kategorija otpada) prenesene su u našu praksu Zakonom o održivom gospodarenju otpadom (NN 94/13, NN 73/17, NN 14/19 i NN 98/19). Navedeni Zakon i pripadajući podzakonski akti su primarni zakonodavni okvir u Republici Hrvatskoj iz područja gospodarenja otpadom. ${ }^{12}$ Zakonom o održivom gospodarenju otpadom reguliraju se ciljevi, način i red prvenstva gospodarenja otpadom, strateški i programski dokumenti, nadležnosti i obveze u gospodarenju otpadom te općenito mjere za sprje- 


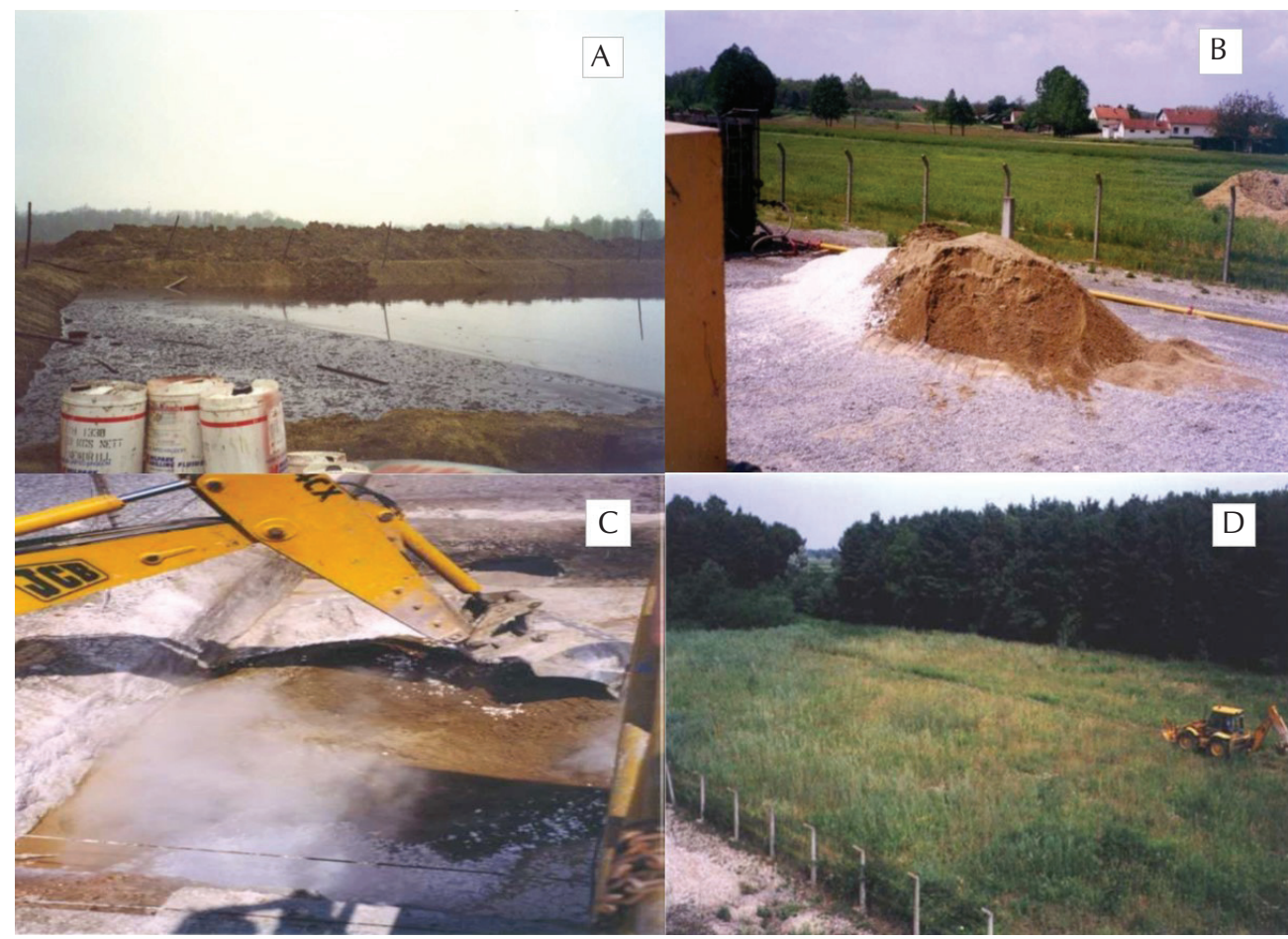

Slika 1 - Prikaz isplačne jame s tekućom fazom i postupak sanacije upotrebom građevinskih strojeva; A - isplačna jama, B - vapno i pijesak za sanaciju, C - miješanje ugušćenog otpadnog materijala s vapnom i pijeskom upotrebom bagera, D - isplačna jama nakon sanacije

Fig. 1 - Mud pit with liquid phase and the remediation process using construction machinery; A mud pit, B - lime and sand for remediation, $\mathrm{C}$ - mixing waste material with lime and sand using excavator, $\mathrm{D}-$ mud pit after remediation

čavanje ili smanjenje štetnog djelovanja otpada na ljudsko zdravlje i okoliš.

Nakon tehnološkog procesa izrade bušotine nastaje određena količina i vrsta otpada. Posjednik otpada dužan je osigurati kategorizaciju otpada prema Katalogu otpada, koji je sastavni dio Pravilnika o katalogu otpada (NN 90/15). Katalog otpada razlikuje 20 grupa koje su, uglavnom, definirane prema djelatnostima nastanka otpada (pojedine grupe povezane su materijalima ili procesima). Svaka pojedina vrsta otpada označena je šesteroznamenkastim ključnim brojem. ${ }^{12}$ Krhotine razrušenih stijena zagađene otpadnom isplakom, prema Pravilniku o katalogu otpada (NN 90/15), svrstavaju se u podgrupu "isplačni muljevi i ostali otpad od bušenja" pod ključnim brojem 0105 . Ukoliko isplačni muljevi sadrže ulja ili općenito opasne tvari (vrste otpada pod ključnim brojevima: $010505 *$ i 0105 06*), predstavljaju opasni otpad za koje je potrebno utvrditi jedno ili više opasnih svojstava, a ako sadrže slatku vodu (otpad pod ključnim brojem 0105 04), predstavljaju neopasni otpad.

Svojstva kao što su eksplozivnost, zapaljivost, infektivnost, mutagenost, svojstvo otpuštanja otrovnih plinova, ekotoksičnost i/ili druga svojstva otpada, definirana Dodatkom III. Zakona o održivom gospodarenju otpadom, definiraju opasni otpad. Ako otpad nastao bušenjem naftnih i plinskih bušotina ima jedno ili više prethodno spomenutih opasnih svojstava, utvrđenih na temelju ispitivanja fizikalno-kemijskih svojstava, spada u kategoriju opasnog otpada.
Osnovni cilj primjene postupka stabilizacije otpada (miješanjem s vapnom i pijeskom) u provedenim ispitivanjima je smanjenje sadržaja ugljikovodika u otpadu i postizanje niske ukupne topljivosti otpada. Početni i stabilizirani otpad se analizira prema hrvatskim normama definiranim u Pravilniku o načinima i uvjetima odlaganja otpada, kategorijama i uvjetima rada za odlagališta otpada (NN 114/15, NN 103/18, NN 56/19). U eluatu otpada se, uz udjele metala, otopljenog organskog ugljika, ukupno otopljenih tvari, sulfata, fluorida i klorida, još dodatno ispituju parametri - udjeli ukupnih ulja i masnoća te mineralnih ulja.

Da bi bio prikladan za odlaganje u isplačnu jamu na lokaciji bušotine, stabilizirani otpad treba zadovoljavati kriterije, odnosno granične vrijednosti parametara eluata koje se odnose na otpad prikladan za prihvat na odlagališta neopasnog otpada a propisane su prethodno spomenutim Pravilnikom.

\section{Eksperimentalni dio}

\subsection{Uzorci}

Osim uzorka ugušćene faze uzorkovanog nakon odvajanja tekuće faze iz isplačne jame, za pripremu mješavina u laboratorijskim uvjetima upotrebljava se živo vapno i pijesak (ili nezagađena zemlja). 
Analizirana su dva uzorka otpada iz isplačnih jama na području Dravske depresije (isplačne jame na lokacijama bušotina Bokšić-42 i Severovci-1). Otpad je uzorkovan na više lokacija u isplačnoj jami te je za laboratorijsku analizu pripremljen kompozitni uzorak početnog otpada (slika 2).

Analiziran je uzorak otpada s povišenim sadržajem organske tvari iz isplačne jame na radnom prostoru bušotine Bokšić-42 (uzorak 1) i uzorak otpada s izrazito visokim vrijednostima ukupno topljive tvari u vodi iz isplačne jame na radnom prostoru istražne bušotine Severovci-1 (uzorak 2).

Uzorkovanje otpadnog materijala provedeno je prema normi HRI CEN/TR 15310-2:2008. Priprema eluata (provjera izluživanja) otpada provedena je prema normi HRN EN 12457-4:2005.

\subsection{Određivanje udjela organske tvari (ekstrakcijal i ukupne topljivosti - početni uzorak otpada}

Prije testa nastajanja stabiliziranog otpada u laboratorijskim uvjetima, u početnom uzorku otpada određen je udio organske tvari dobiven ekstrakcijom s organskim otapalom te sadržaj ukupno topljive tvari u vodi (interna metode), a na temelju tih podataka određuje se količina vapna i pijeska potrebna za izradu stabiliziranog otpada.

Osušeni otpadni mulj (početni uzorak) ekstrahiran je u Sohxlet aparatu refluksiranjem u organskom otapalu (diklormetan/metanol) u trajanju od 120 h. Višak otapala uklonjen je rotacijskom evaporacijom na $50{ }^{\circ} \mathrm{C}$, a kvantitativno je određen udio organske tvari u početnom uzorku otpada.

Kod određivanja ukupne topljivosti u vodi, uzorak početnog otpada i destilirane vode dobro je izmiješan (30 min) na ultrazvučnoj kupelji te profiltriran upotrebom filtarske preše. U dobivenom filtratu određen je sadržaj ukupno topljive tvari u vodi. U odvaganu porculansku zdjelicu (prethodno žarenu do konstantne mase) ulije se $100 \mathrm{ml}$ filtrata, odvaže porculanska zdjelica s filtratom i ishlapi tekućina na vodenoj kupelji. Iz razlike mase prije i nakon isparavanja izračuna se postotak ukupno topljive tvari u vodi (interna metoda).

\subsection{Priprema stabiliziranog otpada u laboratorijskim uvjetima}

Laboratorijski test obično se izvodi na uzorku otpada iz isplačne jame koja nije tretirana vapnom i pijeskom. Uzorak otpada iz isplačne jame dobro je izmiješan u staklenoj laboratorijskoj posudi i usitnjen (drobljenjem). Nakon toga se, na temelju utvrđenog udjela organske tvari i ukupno topljive tvari u vodi u početnom uzorku, postupno dodaje poznata količina vapna i pijeska uz neprekidno miješanje dok ne nastane kruti stabilizirani otpad.

U pripremljenom uzorku stabiliziranog otpada ponovno je određen udio organske tvari i postotak ukupno topljivih tvari u vodi.
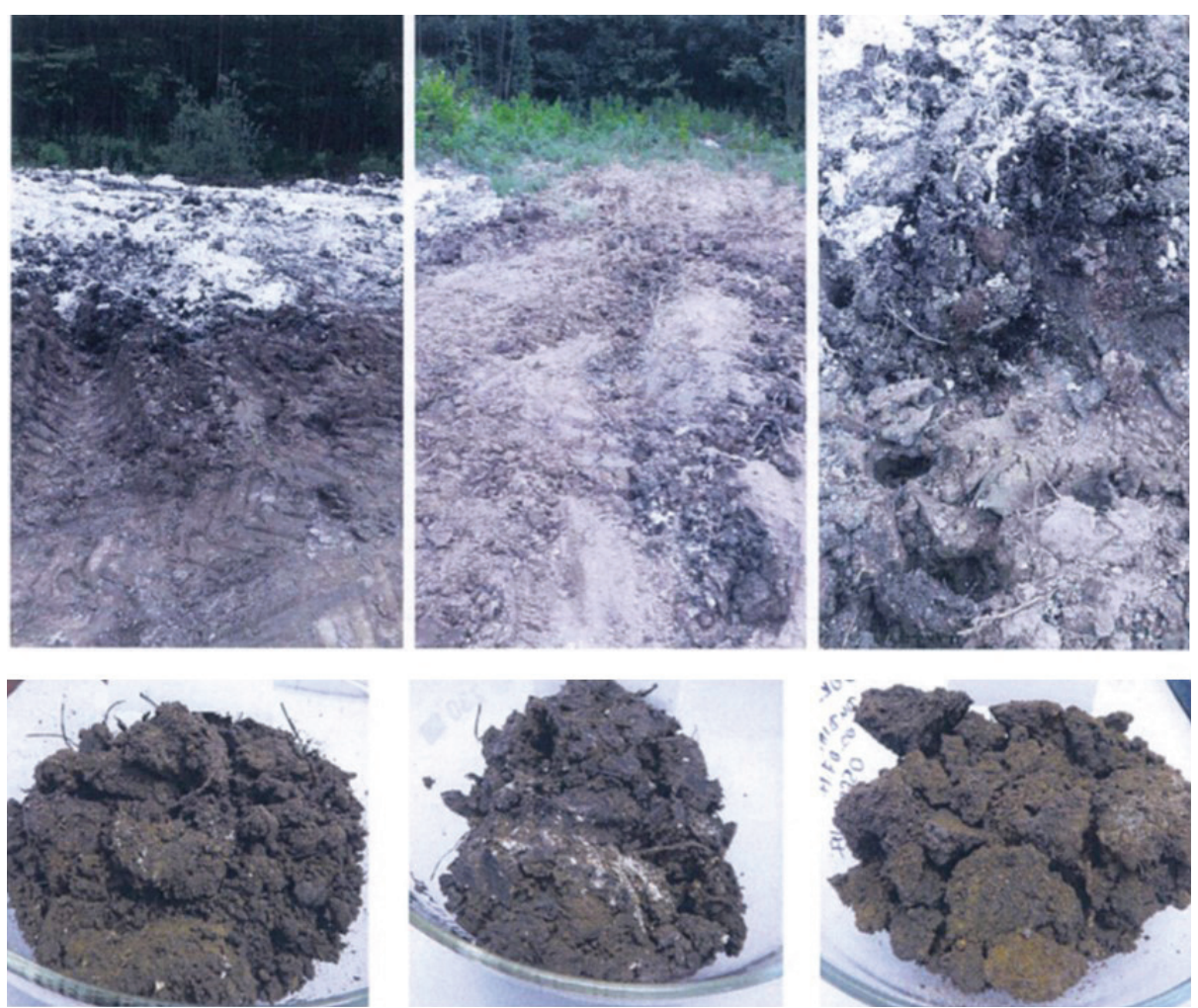

Slika 2 - Prikaz lokaliteta uzorkovanja s pojedinim točkama uzorkovanja

Fig. 2 - Sampling locations with individual sampling points 


\subsection{Fizikalno-kemijska karakterizacija početnog otpada i stabiliziranog otpada pripremljenog u laboratorijskim uvjetima}

Početni i stabilizirani otpad analiziran je prema Pravilniku o načinima i uvjetima odlaganja otpada, kategorijama i uvjetima rada za odlagališta otpada (NN 114/15, NN 103/18, NN 56/19), odnosno prema hrvatskim normama propisanim u tablicama 3 i 4.

Otpad je analiziran prema standardnim metodama: određen je izgled i udio suhe tvari te su određene sljedeće značajke pripremljenog eluata otpada: $\mathrm{pH}$ vrijednost, temperatura, udjeli arsena, barija, kadmija, kroma (ukupni), bakra, žive, molibdena, nikla, olova, antimona, selena i cinka. Kao indikatori organskog zagađenja određeni su u eluatu otpada udjeli: otopljenog organskog ugljika (DOC), ukupnih ulja i masnoća, mineralnih ulja i fenolni indeks. Osnovni indikatori povećane topivosti otpada su koncentracije: ukupno otopljene tvari $\left(180{ }^{\circ} \mathrm{C}\right)$, klorida, sulfata i fluorida.

\section{Rezultati i rasprava}

Rezultati ispitivanja sadržaja organske tvari i ukupno topljive tvari u vodi (temeljni parametri za ocjenu stanja otpada) u dva uzorka početnog i stabiliziranog otpadnog materijala iz isplačnih jama s područja Dravske depresije prikazani su u tablici 2. Prvi uzorak (uzorak 1) sadrži povećani sadržaj organske tvari, a drugi uzorak (uzorak 2) visoke vrijednosti ukupno topljive tvari u vodi. Na temelju rezultata analize početnog uzorka otpada pripremljene su recepture (maseni omjer uzorak : vapno : pijesak za nastajanje stabiliziranog otpada) u laboratorijskim uvjetima dodavanjem vapna i pijeska kako bi se smanjio visok sadržaj organske tvari u prvom uzorku, odnosno visok sadržaj ukupno topljivih tvari u vodi drugog uzorka otpada.

Miješanjem uzorka 1 početnog otpada, pijeska i vapna u masenom omjeru $1: 1: 0,5$ postignut je vrlo nizak sadržaj organske tvari od $0,64 \% \mathrm{~m} / \mathrm{m}$ (tablica 2). Miješanjem uzorka 2 početnog otpada, pijeska i vapna u masenom omjeru $1: 3: 0,7$ smanjena je ukupna topljivost u vodi s $2,50 \% \mathrm{~m} / \mathrm{m}$ na $1,00 \% \mathrm{~m} / \mathrm{m}$ (tablica 2$)$. Vrijednost od $1,00 \% \mathrm{~m} / \mathrm{m}$ u stabiliziranom otpadu je prema iskustvu gornja granična vrijednost koju uzorak pripravljen u laboratorijskim uvjetima treba zadovoljavati kako bi i detaljne fizikalno-kemijske značajke stabiliziranog otpada pokazale vrijednosti koje su ispod granica za neopasni otpad (tablica 4).

U tablici 3 prikazani su rezultati detaljnih fizikalno-kemijska ispitivanja početnog otpada (uzorak $1 \mathrm{i}$ uzorak 2), a u tablici 4 rezultati istih ispitivanja nakon pripreme stabiliziranog otpada prema prethodno opisanoj metodi i u navedenim masenim omjerima komponenata za stabilizaciju otpada.

Gotovo se svi parametri ispituju nakon pripreme eluata otpada kao ključnog koraka kod ispitivanja toksičnosti otpada uslijed ispiranja vodom. pH vrijednost je posebno važna jer o njoj ovisi kemizam vode, pa samim tim i kemijkki sastav eluata. $\mathrm{pH}$ vrijednost početnih uzoraka je relativno visoka, tj. eluat je u alkalnom području, vjerojatno kao posljedica prisutnosti karbonata i bikarbonata i u početnim uzorcima otpada. To znači da je i u početnim uzorcima prisutno vapno koje je dodano na terenu prije samoga početka sanacije.

Oba analizirana uzorka pokazuju niske vrijednosti sadržaja teških metala u eluatu. Većina analiziranih metala se nalazi u eluatu u količini ispod granice kvantifikacije standardne metode, odnosno koncentracije svih analiziranih metala znatno su niže od propisanih graničnih vrijednosti parametara eluata za opasni otpad (tablica 3). Sadržaj teških metala općenito nije visok kod takve vrste otpada, ako se tijekom bušenja upotrebljava isplaka na bazi vode.

Visok sadržaj organske tvari (zagađenje ugljikovodicima) u oba uzorka početnog otpada očituje se u povišenim vrijednostima otopljenog organskog ugljika (tablica 3) koje su posljedica dodatka veće količine podmazivača u isplaku (bazno ulje ili dizelsko gorivo), a razlog može biti i zasićenost ležišnih stijena ugljikovodicima. Osnovni indikatori zagađenja ugljikovodicima naftnog porijekla su visok sadržaj mineralnih ulja i ukupnih fenola (fenolni indeks). Granične vrijednosti za te parametre nisu propisane pravilnicima, ali s obzirom na visoku toksičnost, pogotovo fe-

Tablica 2 - Rezultati ispitivanja sadržaja organske tvari i ukupno topljive tvari u vodi u početnim uzorcima otpada i u laboratoriju pripremljenim uzorcima stabiliziranog otpada

Table 2 - Results of testing the content of organic matter and soluble matter in water in initial waste samples and stabilized waste samples prepared in the laboratory

\begin{tabular}{l|c|c|c|c|c|}
\hline $\begin{array}{l}\text { Značajke } \\
\text { Parameters }\end{array}$ & $\begin{array}{c}\text { Jedinice } \\
\text { Units }\end{array}$ & $\begin{array}{c}\text { Početni } \\
\text { uzorak 1 } \\
\text { Initial Sample 1 }\end{array}$ & $\begin{array}{c}\text { Stabilizirani otpad } \\
\text { uzorak 1 } \\
\text { Stabilized waste } \\
\text { Sample 1 }\end{array}$ & $\begin{array}{c}\text { Početni uzorak 2 } \\
\text { Initial Sample 2 }\end{array}$ & $\begin{array}{c}\text { Stabilizirani otpad } \\
\text { Uzorak 2 }\end{array}$ \\
$\begin{array}{l}\text { Stabilized waste } \\
\text { Sample 2 }\end{array}$ & $\begin{array}{c}\text { Metoda } \\
\text { Methods }\end{array}$ \\
\hline $\begin{array}{l}\text { Sadržaj organske tvari } \\
\text { Organic matter content }\end{array}$ & $\% \mathrm{~m} / \mathrm{m}$ & $\mathbf{1 , 5 5}$ & 0,64 & 0,36 & 0,20 \\
\hline $\begin{array}{l}\text { Ukupno topljive tvari } \\
\text { u vodi } \\
\begin{array}{l}\text { Total soluble matter in } \\
\text { water }\end{array}\end{array}$ & $\% \mathrm{~m} / \mathrm{m}$ & 0,20 & 0,10 & $\mathbf{2 , 5 0}$ & 1,00 \\
\hline
\end{tabular}


Tablica 3 - Fizikalno-kemijske značajke početnih uzoraka otpada

Table 3 - Physical and chemical properties of initial waste samples

\begin{tabular}{|c|c|c|c|c|c|}
\hline $\begin{array}{l}\text { Značajke } \\
\text { Parameters }\end{array}$ & $\begin{array}{l}\text { Jedinice } \\
\text { Units }\end{array}$ & $\begin{array}{c}\text { Granična } \\
\text { vrijednost } \\
\text { Limit values* }\end{array}$ & $\begin{array}{l}\text { Početni } \\
\text { uzorak } 1 \\
\text { Initial } \\
\text { Sample } 1\end{array}$ & $\begin{array}{c}\text { Početni } \\
\text { uzorak } 2 \\
\text { Initial } \\
\text { Sample } 2\end{array}$ & $\begin{array}{l}\text { Metoda } \\
\text { Methods }\end{array}$ \\
\hline $\begin{array}{l}\text { Suha tvar } \\
\text { Dry matter }\end{array}$ & $\% \mathrm{~m} / \mathrm{m}$ & & 70 & 59,6 & HRN EN 14346:2007 \\
\hline $\begin{array}{l}\mathrm{pH} \text { vrijednost } \\
\mathrm{pH} \text { value }\end{array}$ & - & & 11,7 & 10,7 & HRN EN ISO 10523: 2012 \\
\hline $\begin{array}{l}\text { Temperatura } \\
\text { Temperature }\end{array}$ & ${ }^{\circ} \mathrm{C}$ & & - & 22,9 & \\
\hline $\begin{array}{l}\text { Arsen (ICP) } \\
\text { Arsenic (ICP) }\end{array}$ & $\begin{array}{l}\mathrm{mg} \mathrm{kg}^{-1} \text { suhe tvari } \\
\mathrm{mg} \mathrm{kg}^{-1} \text { dry matter }\end{array}$ & 25 & 0,041 & 0,032 & $\begin{array}{l}\text { Interna metoda } \\
\text { In-house method }\end{array}$ \\
\hline $\begin{array}{l}\text { Barij (ICP) } \\
\text { Barium (ICP) }\end{array}$ & $\begin{array}{l}\mathrm{mg} \mathrm{kg}^{-1} \text { suhe tvari } \\
\mathrm{mg} \mathrm{kg}^{-1} \text { dry matter }\end{array}$ & 300 & 0,56 & 3,80 & HRN EN ISO 11885:2010 \\
\hline $\begin{array}{l}\text { Kadmij (ICP) } \\
\text { Cadmium (ICP) }\end{array}$ & $\begin{array}{l}\mathrm{mg} \mathrm{kg}^{-1} \text { suhe tvari } \\
\mathrm{mg} \mathrm{kg}^{-1} \text { dry matter }\end{array}$ & 5 & $<0,001$ & $<0,001$ & HRN EN ISO 11885:2010 \\
\hline $\begin{array}{l}\text { Krom (ukupni) (ICP) } \\
\text { Chrome (total) (ICP) }\end{array}$ & $\begin{array}{l}\mathrm{mg} \mathrm{kg}^{-1} \text { suhe tvari } \\
\mathrm{mg} \mathrm{kg}^{-1} \text { dry matter }\end{array}$ & 70 & $<0,007$ & $<0,007$ & HRN EN ISO 11885:2010 \\
\hline $\begin{array}{l}\text { Bakar (ICP) } \\
\text { Copper (ICP) }\end{array}$ & $\begin{array}{l}\mathrm{mg} \mathrm{kg}^{-1} \text { suhe tvari } \\
\mathrm{mg} \mathrm{kg}^{-1} \text { dry matter }\end{array}$ & 100 & 0,38 & 0,813 & HRN EN ISO 11885:2010 \\
\hline $\begin{array}{l}\text { Živa (ICP) } \\
\text { Mercury (ICP) }\end{array}$ & $\begin{array}{l}\mathrm{mg} \mathrm{kg}^{-1} \text { suhe tvari } \\
\mathrm{mg} \mathrm{kg}^{-1} \text { dry matter }\end{array}$ & 2 & $<0,0005$ & $<0,0005$ & $\begin{array}{l}\text { Interna metoda } \\
\text { In-house method }\end{array}$ \\
\hline $\begin{array}{l}\text { Molibden (ICP) } \\
\text { Molybdenum (ICP) }\end{array}$ & $\begin{array}{l}\mathrm{mg} \mathrm{kg}^{-1} \text { suhe tvari } \\
\mathrm{mg} \mathrm{kg}^{-1} \text { dry matter }\end{array}$ & 30 & 0,17 & 1,48 & HRN EN ISO 11885:2010 \\
\hline $\begin{array}{l}\text { Nikal (ICP) } \\
\text { Nickel (ICP) }\end{array}$ & $\begin{array}{l}\mathrm{mg} \mathrm{kg}^{-1} \text { suhe tvari } \\
\mathrm{mg} \mathrm{kg}^{-1} \text { dry matter }\end{array}$ & 40 & 0,49 & 0,680 & HRN EN ISO 11885:2010 \\
\hline $\begin{array}{l}\text { Olovo (ICP) } \\
\text { Lead (ICP) }\end{array}$ & $\begin{array}{l}\mathrm{mg} \mathrm{kg}^{-1} \text { suhe tvari } \\
\mathrm{mg} \mathrm{kg}^{-1} \text { dry matter }\end{array}$ & 50 & $<0,020$ & 0,480 & HRN EN ISO 11885:2010 \\
\hline $\begin{array}{l}\text { Antimon (ICP) } \\
\text { Antimony (ICP) }\end{array}$ & $\begin{array}{l}\mathrm{mg} \mathrm{kg}^{-1} \text { suhe tvari } \\
\mathrm{mg} \mathrm{kg}^{-1} \text { dry matter }\end{array}$ & 5 & 0,032 & 0,284 & $\begin{array}{l}\text { Interna metoda } \\
\text { In-house method }\end{array}$ \\
\hline $\begin{array}{l}\text { Selen (ICP) } \\
\text { Selenium (ICP) }\end{array}$ & $\begin{array}{l}\mathrm{mg} \mathrm{kg}^{-1} \text { suhe tvari } \\
\mathrm{mg} \mathrm{kg}^{-1} \text { dry matter }\end{array}$ & 7 & $<0,001$ & $<0,001$ & $\begin{array}{l}\text { Interna metoda } \\
\text { In-house method }\end{array}$ \\
\hline $\begin{array}{l}\text { Cink (ICP) } \\
\text { Zinc (ICP) }\end{array}$ & $\begin{array}{l}\mathrm{mg} \mathrm{kg}^{-1} \text { suhe tvari } \\
\mathrm{mg} \mathrm{kg}^{-1} \text { dry matter }\end{array}$ & 200 & $<0,003$ & 0,090 & HRN EN ISO 11885:2010 \\
\hline $\begin{array}{l}\text { Otopljeni organski ugljik (DOC) } \\
\text { Dissolved organic carbon (DOC) }\end{array}$ & $\begin{array}{l}\mathrm{mg} \mathrm{kg}^{-1} \text { suhe tvari } \\
\mathrm{mg} \mathrm{kg}^{-1} \text { dry matter }\end{array}$ & 1000 & 1448 & 4570 & HRN EN 1484:2002 \\
\hline $\begin{array}{l}\text { Ukupna otopljena tvar }\left(180^{\circ} \mathrm{C}\right) \\
\text { Total dissolved solids }\left(180^{\circ} \mathrm{C}\right)\end{array}$ & $\begin{array}{l}\mathrm{mg} \mathrm{kg}^{-1} \text { suhe tvari } \\
\mathrm{mg} \mathrm{kg}^{-1} \text { dry matter }\end{array}$ & 100000 & 7009 & 83020 & $\begin{array}{c}\text { Standard Methods, } 22^{\text {nd }} E d, \\
2540 \text { C: } 2012\end{array}$ \\
\hline $\begin{array}{l}\text { Ukupna ulja i masnoće } \\
\text { Total oils and grease }\end{array}$ & $\begin{array}{l}\mathrm{mg} \mathrm{kg}^{-1} \text { suhe tvari } \\
\mathrm{mg} \mathrm{kg}^{-1} \text { dry matter }\end{array}$ & & 28,0 & 6023 & $\begin{array}{c}\text { Standard Methods, } 22^{\text {nd }} E d, \\
5520 \text { B:2012 }\end{array}$ \\
\hline $\begin{array}{l}\text { Mineralna ulja } \\
\text { Mineral oils }\end{array}$ & $\begin{array}{l}\mathrm{mg} \mathrm{kg}^{-1} \text { suhe tvari } \\
\mathrm{mg} \mathrm{kg}^{-1} \text { dry matter }\end{array}$ & & - & 206 & $\begin{array}{l}\text { Interna metoda } \\
\text { In-house method }\end{array}$ \\
\hline $\begin{array}{l}\text { Fluoridi } \\
\text { Flouride }\end{array}$ & $\begin{array}{l}\text { mg kg }{ }^{-1} \text { suhe tvari } \\
\mathrm{mg} \mathrm{kg}^{-1} \text { dry matter }\end{array}$ & 500 & 3,8 & 110 & HRN EN ISO 10304-1:2009 \\
\hline $\begin{array}{l}\text { Kloridi } \\
\text { Chloride }\end{array}$ & $\begin{array}{l}\text { mg kg }{ }^{-1} \text { suhe tvari } \\
\mathrm{mg} \mathrm{kg}^{-1} \text { dry matter }\end{array}$ & 25000 & 290 & 30160 & HRN EN ISO 10304-1:2009 \\
\hline $\begin{array}{l}\text { Sulfati } \\
\text { Sulphate }\end{array}$ & $\begin{array}{l}\text { mg kg }{ }^{-1} \text { suhe tvari } \\
\mathrm{mg} \mathrm{kg}^{-1} \text { dry matter }\end{array}$ & 50000 & 170 & 1130 & HRN EN ISO 10304-1:2009 \\
\hline $\begin{array}{l}\text { Fenolni indeks } \\
\text { Phenol index }\end{array}$ & $\begin{array}{l}\mathrm{mg} \mathrm{kg}^{-1} \text { suhe tvari } \\
\mathrm{mg} \mathrm{kg}^{-1} \text { dry matter }\end{array}$ & & 1,61 & 1,21 & HRN ISO 6439:1998 \\
\hline
\end{tabular}

* granične vrijednosti parametra eluata opasnog otpada (tekuće/kruto $=10 \mid \mathrm{kg}^{-1}$ ), propisane Pravilnikom o načinima i uvjetima odlaganja otpada, kategorijama i uvjetima rada za odlagališta otpada (NN 114/15, 103/18, 56/19) i Odlukom Vijeća EU 2033/33/EC

* limit values for the hazardous waste eluate parameters (liquid/solid $=10 \mathrm{l} \mathrm{kg}{ }^{-1}$ ), laid down by the Ordinance on methods and conditions of waste disposal, categories and operational conditions for landfills (NN 114/15, 103/18, 56/19) and by the EU Council Decision 2033/33/EC 
Tablica 4 - Fizikalno-kemijske značajke stabiliziranih uzoraka otpada (laboratorijski test)

Table 4 - Physical and chemical properties of stabilized waste samples (laboratory test)

\begin{tabular}{|c|c|c|c|c|c|}
\hline $\begin{array}{l}\text { Značajke } \\
\text { Parameters }\end{array}$ & $\begin{array}{l}\text { Jedinice } \\
\text { Units }\end{array}$ & $\begin{array}{c}\text { Granična } \\
\text { vrijednost } \\
\text { Limit values* }\end{array}$ & $\begin{array}{l}\text { Stabilizirani } \\
\text { otpad } \\
\text { uzorak } 1 \\
\text { Stabilized waste } \\
\text { Sample } 1\end{array}$ & $\begin{array}{c}\text { Stabilizirani } \\
\text { otpad } \\
\text { uzorak } 2 \\
\text { Stabilized waste } \\
\text { Sample } 2\end{array}$ & $\begin{array}{l}\text { Metoda } \\
\text { Methods }\end{array}$ \\
\hline $\begin{array}{l}\text { Suha tvar } \\
\text { Dry matter }\end{array}$ & $\% \mathrm{~m} / \mathrm{m}$ & & 75,4 & 92,2 & HRN EN 14346:2007 \\
\hline $\begin{array}{l}\mathrm{pH} \text { vrijednost } \\
\mathrm{pH} \text { value }\end{array}$ & - & & 11,4 & 12,7 & HRN EN ISO 10523: 2012 \\
\hline $\begin{array}{l}\text { Temperatura } \\
\text { Temperature }\end{array}$ & ${ }^{\circ} \mathrm{C}$ & & 23,2 & 20,8 & \\
\hline $\begin{array}{l}\text { Arsen (ICP) } \\
\text { Arsenic (ICP) }\end{array}$ & $\begin{array}{l}\text { mg kg-1 suhe tvari } \\
\mathrm{mg} \mathrm{kg}^{-1} \text { dry matter }\end{array}$ & 2 & 0,038 & $<0,001$ & $\begin{array}{l}\text { Interna metoda } \\
\text { In-house method }\end{array}$ \\
\hline $\begin{array}{l}\text { Barij (ICP) } \\
\text { Barium (ICP) }\end{array}$ & $\begin{array}{l}\mathrm{mg} \mathrm{kg}^{-1} \text { suhe tvari } \\
\mathrm{mg} \mathrm{kg}^{-1} \text { dry matter }\end{array}$ & 100 & 0,17 & 13,4 & HRN EN ISO 11885:2010 \\
\hline $\begin{array}{l}\text { Kadmij (ICP) } \\
\text { Cadmium (ICP) }\end{array}$ & $\begin{array}{l}\mathrm{mg} \mathrm{kg}^{-1} \text { suhe tvari } \\
\mathrm{mg} \mathrm{kg}^{-1} \text { dry matter }\end{array}$ & 1 & $<0,001$ & $<0,001$ & HRN EN ISO 11885:2010 \\
\hline $\begin{array}{l}\text { Krom (ukupni) (ICP) } \\
\text { Chrome (total) (ICP) }\end{array}$ & $\begin{array}{l}\text { mg kg-1 suhe tvari } \\
\mathrm{mg} \mathrm{kg}^{-1} \text { dry matter }\end{array}$ & 10 & $<0,007$ & $<0,007$ & HRN EN ISO 11885:2010 \\
\hline $\begin{array}{l}\text { Bakar (ICP) } \\
\text { Copper (ICP) }\end{array}$ & $\begin{array}{l}\text { mg kg-1 suhe tvari } \\
\mathrm{mg} \mathrm{kg}^{-1} \text { dry matter }\end{array}$ & 50 & 0,847 & 0,115 & HRN EN ISO 11885:2010 \\
\hline $\begin{array}{l}\text { Živa (ICP) } \\
\text { Mercury (ICP) }\end{array}$ & $\begin{array}{l}\mathrm{mg} \mathrm{kg}^{-1} \text { suhe tvari } \\
\mathrm{mg} \mathrm{kg}^{-1} \text { dry matter }\end{array}$ & 0,2 & $<0,0005$ & $<0,0005$ & $\begin{array}{l}\text { Interna metoda } \\
\text { In-house method }\end{array}$ \\
\hline $\begin{array}{l}\text { Molibden (ICP) } \\
\text { Molybdenum (ICP) }\end{array}$ & $\begin{array}{l}\mathrm{mg} \mathrm{kg}^{-1} \text { suhe tvari } \\
\mathrm{mg} \mathrm{kg}^{-1} \text { dry matter }\end{array}$ & 10 & 0,12 & 0,200 & HRN EN ISO 11885:2010 \\
\hline $\begin{array}{l}\text { Nikal (ICP) } \\
\text { Nickel (ICP) }\end{array}$ & $\begin{array}{l}\mathrm{mg} \mathrm{kg}^{-1} \text { suhe tvari } \\
\mathrm{mg} \mathrm{kg}^{-1} \text { dry matter }\end{array}$ & 10 & $<0,015$ & $<0,015$ & HRN EN ISO 11885:2010 \\
\hline $\begin{array}{l}\text { Olovo (ICP) } \\
\text { Lead (ICP) }\end{array}$ & $\begin{array}{l}\text { mg kg-1 suhe tvari } \\
\mathrm{mg} \mathrm{kg}^{-1} \text { dry matter }\end{array}$ & 10 & $<0,020$ & $<0,020$ & HRN EN ISO 11885:2010 \\
\hline $\begin{array}{l}\text { Antimon (ICP) } \\
\text { Antimony (ICP) }\end{array}$ & $\begin{array}{l}\text { mg kg-1 suhe tvari } \\
\mathrm{mg} \mathrm{kg}^{-1} \text { dry matter }\end{array}$ & 0,7 & 0,034 & $<0,0005$ & $\begin{array}{l}\text { Interna metoda } \\
\text { In-house method }\end{array}$ \\
\hline $\begin{array}{l}\text { Selen (ICP) } \\
\text { Selenium (ICP) }\end{array}$ & $\begin{array}{l}\mathrm{mg} \mathrm{kg}^{-1} \text { suhe tvari } \\
\mathrm{mg} \mathrm{kg}^{-1} \text { dry matter }\end{array}$ & 0,5 & $<0,001$ & $<0,001$ & $\begin{array}{l}\text { Interna metoda } \\
\text { In-house method }\end{array}$ \\
\hline $\begin{array}{l}\text { Cink (ICP) } \\
\text { Zinc (ICP) }\end{array}$ & $\begin{array}{l}\mathrm{mg} \mathrm{kg}^{-1} \text { suhe tvari } \\
\mathrm{mg} \mathrm{kg}^{-1} \text { dry matter }\end{array}$ & 50 & $<0,003$ & $<0,003$ & HRN EN ISO 11885:2010 \\
\hline $\begin{array}{l}\text { Otopljeni organski ugljik (DOC) } \\
\text { Dissolved organic carbon (DOC) }\end{array}$ & $\begin{array}{l}\text { mg kg-1 suhe tvari } \\
\mathrm{mg} \mathrm{kg}^{-1} \text { dry matter }\end{array}$ & 800 & 360 & 178 & HRN EN 1484:2002 \\
\hline $\begin{array}{l}\text { Ukupna otopljena tvar }\left(180^{\circ} \mathrm{C}\right) \\
\text { Total dissolved solids }\left(180^{\circ} \mathrm{C}\right)\end{array}$ & $\begin{array}{l}\text { mg kg-1 suhe tvari } \\
\mathrm{mg} \mathrm{kg}^{-1} \text { dry matter }\end{array}$ & 60000 & 3021 & 25557 & $\begin{array}{c}\text { Standard Methods, } 22^{\text {nd }} \text { Ed, } \\
2540 \text { C:2012 }\end{array}$ \\
\hline $\begin{array}{l}\text { Ukupna ulja i masnoće } \\
\text { Total oils and grease }\end{array}$ & $\begin{array}{l}\mathrm{mg} \mathrm{kg}-1 \text { suhe tvari } \\
\mathrm{mg} \mathrm{kg}^{-1} \text { dry matter }\end{array}$ & & 111 & 128 & $\begin{array}{c}\text { Standard Methods, } 22^{\text {nd }} E d \text {, } \\
5520 \text { B:2012 }\end{array}$ \\
\hline $\begin{array}{l}\text { Mineralna ulja } \\
\text { Mineral oils }\end{array}$ & $\begin{array}{l}\text { mg kg-1 suhe tvari } \\
\mathrm{mg} \mathrm{kg}^{-1} \text { dry matter }\end{array}$ & & 10 & 8,4 & $\begin{array}{l}\text { Interna metoda } \\
\text { In-house method }\end{array}$ \\
\hline $\begin{array}{l}\text { Fluoridi } \\
\text { Flouride }\end{array}$ & $\begin{array}{l}\text { mg kg-1 suhe tvari } \\
\mathrm{mg} \mathrm{kg}^{-1} \text { dry matter }\end{array}$ & 150 & 8,6 & 2,7 & HRN EN ISO 10304-1:2009 \\
\hline $\begin{array}{l}\text { Kloridi } \\
\text { Chloride }\end{array}$ & $\begin{array}{l}\text { mg kg-1 suhe tvari } \\
\mathrm{mg} \mathrm{kg}^{-1} \text { dry matter }\end{array}$ & 15000 & 43 & 3898 & HRN EN ISO 10304-1:2009 \\
\hline $\begin{array}{l}\text { Sulfati } \\
\text { Sulphate }\end{array}$ & $\begin{array}{l}\text { mg kg-1 suhe tvari } \\
\mathrm{mg} \mathrm{kg}^{-1} \text { dry matter }\end{array}$ & 20000 & 190 & 120 & HRN EN ISO 10304-1:2009 \\
\hline $\begin{array}{l}\text { Fenolni indeks } \\
\text { Phenol index }\end{array}$ & $\begin{array}{l}\mathrm{mg} \mathrm{kg}^{-1} \text { suhe tvari } \\
\mathrm{mg} \mathrm{kg}^{-1} \text { dry matter }\end{array}$ & & 0,26 & $<0,05$ & HRN ISO 6439:1998 \\
\hline
\end{tabular}

"granične vrijednosti parametra eluata neopasnog otpada (tekuće/ $\mathrm{kruto}=10 \mathrm{l} \mathrm{kg}{ }^{-1}$ ), propisane Pravilnikom o načinima i uvjetima odlaganja otpada, kategorijama i uvjetima rada za odlagališta otpada (NN 114/15, 103/18, 56/19) i Odlukom Vijeća EU 2033/33/EC

*limit values for the non-hazardous waste eluate parameter (liquid/solid $=101 \mathrm{~kg}^{-1}$ ), laid down by the Ordinance on methods and conditions of waste disposal, categories and operational conditions for landfills (NN 114/15, 103/18, 56/19) and by the EU Council Decision 2033/33/EC 
nola kao aromatskih spojeva, njihov sadržaj treba biti vrlo nizak. S obzirom na liofilni karakter naftnih ugljikovodika, oni se u vodi raspoređuju u obliku sitnih kapljica ili tankog sloja na površini, što utječe na smanjenje topljivosti kisika u vodi.

U uzorku 1 koji ima povišene vrijednosti sadržaja organske tvari (tablica 2) koncentracija otopljenog organskog ugljika (DOC) prelazi graničnu vrijednost propisanu za opasni otpad i iznosi $1448 \mathrm{mg} \mathrm{kg}^{-1}$ suhe tvari (tablica 3). Pripremljenom recepturom (za stabilizirani otpad) u laboratorijskim uvjetima dodatkom vapna i pijeska vrijednost otopljenog organskog ugljika je smanjena na $360 \mathrm{mg} \mathrm{kg}^{-1}$ suhe tvari (tablica 4), tj. na vrijednost koja je ispod granične vrijednosti propisane za neopasni otpad (800 $\mathrm{mg} \mathrm{kg}^{-1}$ suhe tvari). Vrijednost fenolnog indeksa također je smanjena $\mathrm{s}$ $1,6 \mathrm{mg} \mathrm{kg}^{-1}$ suhe tvari u početnom uzorku 1 (tablica 3) na $0,26 \mathrm{mg} \mathrm{kg}^{-1}$ suhe tvari u uzorku stabiliziranog otpada (tablica 4).

U početnom uzorku 2 koji ima povišenu vrijednost ukupne topljivosti u vodi $(2,5 \% \mathrm{~m} / \mathrm{m})$ koncentracija otopljenog organskog ugljika (DOC) iznosi $4570 \mathrm{mg} \mathrm{kg}^{-1}$ suhe tvari (tablica 3), što znači da premašuje graničnu vrijednost propisanu za opasni otpad (1000 $\mathrm{mg} \mathrm{kg}^{-1}$ suhe tvari) za više od četiri puta. Sadržaj klorida u početnom uzorku 2 također je iznad granične vrijednosti propisane za opasni otpad (25000 $\mathrm{mg} \mathrm{kg}^{-1}$ suhe tvari) i iznosi čak $30160 \mathrm{mg} \mathrm{kg}^{-1}$ suhe tvari. Visoka koncentracija klorida u krhotinama razrušenih stijena zagađenih isplakom uglavnom potječe od soli $(\mathrm{NaCl})$, kao aditiva dodanog isplaci. Uz kloride može biti povišen i sadržaj sulfata, koji potječe iz barita $\left(\mathrm{BaSO}_{4}\right)$ kao sastavnog dijela korištene isplake. Kloridi i sulfati često čine najveći udio ukupno otopljene tvari. Pripremljenom recepturom (za stabilizirani otpad uzorka 2) u laboratorijskim uvjetima, dodatkom vapna i pijeska, vrijednost otopljenog organskog ugljika je smanjena s $4570 \mathrm{mg} \mathrm{kg}^{-1}$ suhe tvari u početnom uzorku 2 na vrijednost od $178 \mathrm{mg} \mathrm{kg}^{-1}$ suhe tvari u stabiliziranom otpadu, koja je daleko ispod granične vrijednosti propisane za neopasni otpad $\left(800 \mathrm{mg} \mathrm{kg}^{-1}\right.$ suhe tvari). Sadržaj klorida u pripremljenom stabiliziranom otpadu uzorka 2 također je smanjen na prihvatljivih $3898 \mathrm{mg} \mathrm{kg}^{-1}$ suhe tvari (tablica 4).

\section{Zaključak}

Postupak stabilizacije upotrebom vapna i pijeska pokazao se kao vrlo učinkovit postupak obrade krhotina razrušenih stijena zagađenih otpadnom isplakom. Upotrebom isplake na bazi vode, sadržaj organske tvari u otpadu obično ne prelazi $3 \% \mathrm{~m} / \mathrm{m}$. Ukupna topljivost otpada u vodi također ovisi o sastavu same isplake. Postupkom stabilizacije otpada upotrebom vapna i pijeska moguće je dobiti stabilizirani otpad koji prema svim fizikalno-kemijskim značajkama ne prelazi propisane granične vrijednosti za neopasni otpad te se otpad kao takav može odlagati kao kruti neopasni otpad $\mathrm{u}$ isplačnu jamu na lokaciji bušotine.

\section{ZAHVALA}

Na poseban način se zahvaljujem kolegici Mariji Zvolinski na predanom radu, izvrsnim analitičkim vještinama i pomoći kod pripreme uzoraka stabiliziranog otpada u laboratorijskim uvjetima.

\section{Literatura \\ References}

1. N. Gaurina-Međimurec, G. Durn, D. Slovenec, N. Tadej, M. Čović, F. Bašić, I. Kisić, M. Mesić, B, Veronek, S. Mesić, R. Gabrić, Studija uspješnosti postupka i rezultata solidifikacije centralne otpadne jame pogona Lipovljani i utjecaj navedenog zahvata na okoliš, Rudarsko-geološko-naftni fakultet, Zagreb, 2001.

2. M. Baričević, Zbrinjavanje tehnološkog otpada na eksploatacijskom polju "Žutica", diplomski rad, Rudarsko-geološko-naftni fakultet, Zagreb, 2016.

3. M. S. Al-Ansary, A. Al-Tabbaa, Stabilisation/solidification of synthetic North Sea drill cuttings containing oil and chloride, Proceedings of the Int. Conf. on stabilisation/solidification treatment and remediation, Cambridge, 2005., doi: https:// doi.org/10.1201/9781439833933.ch5.

4. M. S Al-Ansary, A. Al-Tabbaa, Stabilisation/solidification of Synthetic Petroleum Drill Cuttings. J. Hazard. Mater. 141 (2) (2007) 410-421, doi: https://doi.org/10.1016/j.jhazmat.2006.05.079.

5. N. Gaurina-Međimurec, Predavanja: Bušotinski fluidi, Rudarsko-geološko-naftni fakultet, Zagreb, 2009.

6. B. Roddie, A. Skadsheim, D. Runciman, G. Kjeilen, Cuttings Pile Toxicity, Project 1.2: UKOOA Drill Cuttings Joint Industry Project and Rogaland Research, UK and Norway, 1999.

7. S. A. Leonard, J. A. Stegemann, Stabilization/solidification of petroleum drill cuttings, J. Hazard. Mater. 174 (2010) 463472, doi: https://doi.org/10.1016/j.jhazmat.2009.09.075.

8. S. E. O. Opete, I. A. Mangibo, E. T. lyagba, Stabilization/solidification of synthetic Nigerian drill cuttings, AJEST 4 (3) (2010) 149-153, doi: https://doi.org/10.5897/AJEST09.012.

9. S. Ghasemi, S. Gitipour, F. Ghazban, H. Hedayati, Treatment of Petroleum Drill Cuttings Using Stabilization/Solidification Method by Cement and Modified Clay Mixes, IJHSE 4 (3) (2017) 781-787.

10. J. R. Conner, Chemical Fixation and Solidification of Hazardous Wastes, Van Nostrand Reinhold, New York, 1990.

11. U. S. EPA Technical Resource Document Solidification-stabilization and Its Application to Waste Materials US Environmental Protection Agency, 1993.

12. K. El Sabeh, N. Gaurina-Međimurec, K. Novak Mavar, Bioremediacija zauljenog otpada iz procesa naftnog rudarstva, Nafta i plin 39 (2019) 123-131. 
SUMMARY

\section{Stabilization of Drill Cuttings Contaminated with Waste Mud \\ Slavica Marinović, Tamara Troskot Čorbić, Tihana Goričnik, Nada Uzorinac Nasipak, and Vedrana Čizmek}

In the Croatian oil and gas industry, significant quantities of drill cuttings are produced annually. The drill cuttings are contaminated with waste mud being heterogeneous waste which comprises hydrocarbons, heavy metals and chlorides. Currently, the treatment option for these drill cuttings is stabilization method using lime and sand as binder. The procedure of stabilized waste preparation in laboratory conditions on two samples of drill cuttings from Drava Depression is described. Prior to the stabilization test under laboratory conditions, it was necessary to determine the content of organic matter in the initial waste sample using organic solvent extraction method, and the content of total soluble matter in water. On the basis of these two parameters, the amount of lime and sand required to produce stabilized waste were determined. Initial and stabilized waste samples were analysed according to standard methods. The results indicated that the process of stabilization of waste using lime and sand enabled the transformation of an initial waste sample classified as hazardous waste into non-hazardous waste.

\section{Keywords}

Drill cuttings, stabilization, lime, sand, hazardous waste

Ina-Industrija nafte d.d.

Original scientific paper

Lovinčićeva 4

10000 Zagreb

Croatia 